\title{
TABIE DES MATIÉRES.
}

Réflexions sur l'étude des langues asiatiques, adrèssées à Sir James Mackintosh

Lettre à $M$. Horace $H$. Wilson, ancien secrétaire de la Société Asiatique à Calcutta, élu prọfesseur à l'université d'Oxfard

\section{A PPENDICE.}

A. Prospectus of a plan for translating and publishing such interesting and valuable works on Eastern History, Sciences, and Belles-Lettres as are etc. . . I I

B. Copy of a letter of the Rev. Professor Lee to Sir Alexander Johnston, Knt. . . . . ${ }^{1}{ }_{17}^{8}$

C. Letter to the Honorable Court of Directors of the East-India Company . . . . . . ${ }_{1} 82$

D. Comparaison de quelques passages du Hitôpadésa dans la traduction de $S$. $W$. Jones et dans celle de M. Wilkins . . . . . . . . . 185

E. Explication d'une énigme . . . . . . . $\quad .197$

F. Sanscrit Professorship . . . . . . 200 


\section{ERRATUM.}

P. $\$ 46$, ligne 26. Ce vers sanscrit a été réimprimé exactetement comme il se lit dans les Rccherclies Asiatiques, mais on a oublié d'y faire une correction nécessaire. Au lieu de बउईत्वन il fant lire: पउर्डन्वेन. 